\title{
CHAMADA DE TRABALHOS
}

\section{NEGÓCIOS DE IMPACTO SOCIAL}

Editor chefe: Eduardo Diniz (FGV-EAESP) | Editor adjunto: Martin Jayo (EACH-USP) | Editor convidado: Edgard Barki (FGV-EAESP)

Os negócios de impacto social propõem um modelo de organização híbrida que combina as competências de gestão do setor privado com os conhecimentos de gestão social do terceiro setor. São organizações que objetivam resolver um problema social, utilizando mecanismos de mercado. As organizações atuando neste setor têm diversos desafios:

- É possível criar um modelo lucrativo e sustentável que tenha como foco o impacto social?

- Como escalar os negócios de forma a ter mais impacto?

- Como criar a melhor proposta de valor?

- Como capturar o valor do negócio?

- Qual é o papel das grandes empresas no setor de negócios de impacto social?

- Qual é o papel do ecossistema do setor de impacto social, incluindo aceleradores, investidores de impacto e incubadoras?

Com essas questões em mente, a GVcasos - Revista Brasileira de Casos de Ensino em Administração oferece seu espaço para a divulgação de casos de ensino enfocando práticas bem ou mal sucedidas no setor de negócios de impacto social.

\section{TEMAS E TÓPICOS}

Alguns temas possíveis a serem trabalhados pelos casos desta edição especial são:

- Desafios e oportunidades dos negócios de impacto social

- O papel e desafios do empreendedor

- Novos negócios e modelos de gestão

- O papel dos diferentes atores: empresários, aceleradores, incubadoras, investidores de impacto, pequenas empresas, grandes empresas e governo

- A importância das parcerias e redes em campo

- Avaliação do impacto social

- O papel da tecnologia e da inovação

\section{APRESENTAÇÃO DE TRABALHOS}

Os casos submetidos não devem ter sido publicados, aceitos para publicação, ou estar atualmente sob consideração para publicação em outro periódico.

Para ser elegível para a revisão do artigo devem ser configurados de acordo com as diretrizes da CVcasos (disponíveis em www.fgv.br/gvcasos).

Os trabalhos deverão ser escritos em português, inglês ou espanhol. A submissão deve ser feita através do sistema de submissões da CVcasos, disponível em www.fgv.br/gvcasos.

Casos adequados serão submetidos a um processo de double blind review.

\section{MAIS INFORMAÇÕES: www.fgv.br/gvcasos}

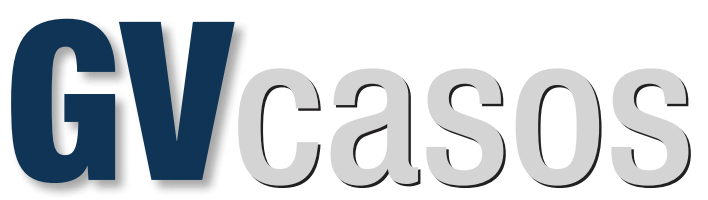

